DOI: $10.20472 / E F C .2020 .013 .013$

\author{
ANDREY PUSHKAREV \\ Ural Federal University, Russian Federation \\ ANNA SENNIKOVA \\ Ural Federal University, Russian Federation \\ OLEG MARIEV \\ Ural Federal University, Russian Federation
}

\title{
ECONOMETRIC ESTIMATION OF MARKET SELECTION IN RUSSIA: DIFFERENT PERFORMANCE INDICATORS
}

\begin{abstract}
:
This paper contributes to the analysis of several firm performance indicators for estimating market selection forces on the industrial level by using econometric estimation method. For the comparison we employ data on Russian manufacturing firms for the period from 2006 to 2017. The sample contains more than 79 thousand enterprises for a period of 2 to 12 years. This research is focused on such performance indicators as labor productivity, total factor productivity (TFP) and profit per employee. We compare results of the econometrical examination of the link between each of them and the firm growth. The main result implies that the bulk of the impact of productivity variables relates to efficiency changes more than to absolute differences of productivity levels across firms. Comparing three performance indicators we see that the median values of total explanatory ability are close for the labor productivity and total factor productivity. This holds true also on the level of individual industries. The results for profit per employee provide slightly higher median estimate. The research shows that such indicator as profit of the firm can well substitute labor productivity indicator in the market selection and competition research.
\end{abstract}

\section{Keywords:}

productivity, market selection, Russian firms

JEL Classification: L11, D40 


\section{Introduction}

One can measure firm performance with a variety of indicators. Although each of them has their own specificity, they all used to represent how well firm performs on the market. Main goal of this research is to compare some performance indicators that can be used when analyzing market selection.

Choosing an appropriate indicator is an important task when measuring market success of the firm and the process of market selection. By using econometric estimation method one can directly look at the productivity-growth relationship within a standard firm-level regression framework. We look at the strength of the market selection by estimating the explanatory power of productivity as predictor of firm growth. The main specification accounts for the overall explanatory power of relative levels of indicator versus over time changes of relative productivities or profit per employee. It should be beneficial to understand what performance indicators are suitable for the research of the competition, what results do different indicators produce and how these results compare in case of Russian firms. In this paper, we compare labor productivity, total factor productivity and profit per employee of firms to this purpose.

For this, we employ a dataset of over 79 thousand Russian manufacturing firms for the period from 2006 to 2017 . Then we perform standard firm-level regression framework to assess the market selection in Russian industries. To our knowledge the econometrical examination of the link between firm growth and firm performance with the profits per employee indicator and comparing the results for different performance indicators is the first study on Russian data.

The rest of the work is organized as follows. In Section 1, we give a brief overview of recent research on market selection and performance indicators. Section 2 describes our data and methodology. In Section 3 we present and discuss our results. Section 4 concludes.

\section{Background and Existing Research}

The literature on industrial organization uses a number of different performance indicators for firms. The literature review by Al-Matari et al. (2014) provides a list of variables that are frequently used to represent firms' performance. According to them, the five most popular are return on assets, return on equity, return on sales, return on investment, and profit. In addition, in more recent studies on market selection, labor productivity has been frequently used.

For example, using this indicator Dosi et al. (2015) perform a firm-level regression and measure market selection for France, Germany, the UK, and the USA. They find the role of market forces for revenue growth ranging from $13-14 \%$ for the UK and US and $16-18 \%$ for Germany and France. They also found that of the main impact of productivity variables relates to efficiency changes more than to absolute differences of productivity levels across firms in all the countries. Same technique has been used for Russia by Savin et al. (2020). For Russian manufacturing industries market selection effect estimated by using labor productivity is also found to be weak, the explanatory ability of dynamic component of profit is stronger. Apart from that, Savin et al. (2020) have also used the total factor productivity and confirmed low role of the market section forces.

Bottazzi and Secchi (2012) for the analysis of the competition effects adopt profitability and productivity of firms. They highlight the fact that profitability-growth or productivity-growth relations are supported theoretically but find limited empirical evidence. Similar results have been also obtained by Coad (2007). It is also worth mentioning that Foster et al. (2008) find that selection is 
tightly connected to the profitability. Therefore, we argue that this factor is worth adding in our analysis.

Generally, understanding and properly estimating performance is important for both entrepreneurship research and practice as it is closely connected to the firms' survival on the market. For example, Delmar et al. (2013) based on Swedish firm-level data find a strong positive effects of firms' profitability on their survival on the market. Dosi et al. (2017) show that productivity as a measure of performance plays key role in the survival of U.S. firms.

In the following, we proceed with the three above mentioned indicators: labor productivity, TFP and profit per employee.

\section{Data and Methods}

The econometric estimation method is used to determine the degree of influence of changes in the firm's performance indicators on the dynamics of their performance growth. We compare such predictors as labor productivity, total factor productivity and profit to this purpose.

For the empirical analysis we employ data on Russian manufacturing firms for the period from 2006 to 2017 (industries 10 to 32 according to NACE2 classification). Data is obtained from the Ruslana database provided by Bureau van Dijk (BvD). The sample contains more than 79 thousand enterprises for a period of 2 to 12 years. We take into account both enterprises that existed and are observed throughout the period and enterprises that either left the market or ceased to provide information in BvD.

We also impose several limitations on the data necessary for the analysis. Namely, we only analyze firms with more than 20 employees and consider only firms that are observed for two consecutive years and censor our data by removing top and bottom $1 \%$ of observations in revenue growth and performance. This done since top $1 \%$ of the firms greatly differs from all other firms.

All three performance indicators we concentrate on are calculated in real prices in USD (2005 is used as a base year). Labor productivity is computed as value added divided by the number of employees, where value added is calculated as difference between revenue and total costs, excluding labor costs. As labor costs are not directly available in Ruslana database, we resort to the approximation of this indicator, calculated as a sector-region average yearly wage reported by Rosstat multiplied by the number of employees.

Profit per employee in turn is defined as a difference between company's total revenue and total costs, divided by the number of employees.

Total factor productivity (TFP), is calculated using Van Beveren (2012) approach, by estimating log-linearized Cobb-Douglas production function.

$$
y_{i, t}=\beta_{0}+\beta_{1} l_{i, t}+\beta_{k} k_{i, t}+e_{i, t}
$$

where $y_{i, t}$ is a logarithm of firm's value added, $l_{i, t}$ is a logaritm of the number of this firm's employees and $k_{i, t}$ is real total assets of the firm $i .{ }^{1}$ TFP capturing the technology factor as a result is:

$$
\widehat{\omega}_{i t}=y_{i, t}-\hat{\beta}_{1} l_{i, t}-\hat{\beta}_{k} k_{i, t}
$$

\footnotetext{
${ }^{1}$ Total assets is the only available assets indicator in the Ruslana database
} 
An econometric approach for assessing the relationship between firm growth and productivity was first considered in the work of Bottazzi et al. (2010) based on data from France and Italy. The authors conducted an empirical assessment that determines the role of the productivity level in explaining the dynamics of sales growth of firms. Dosi et al. (2015) applied a similar approach to data for France, Germany, the United Kingdom, and the United States. For Russia, a similar study was conducted in the works of Savin et al. $(2019,2020)$. In these studies, the explanatory power of productivity for the success of firms fluctuated at the level of $3-20 \%$, which indicates the low efficiency of the market selection mechanism.

The specification of model includes the performance growth as a dependent variable (one by one) and the aforecited indicators as predictors. In order to obtain results on the share of the explained variance, the regression coefficients are used to estimate correlated random effects. We pay attention to the static and dynamic components, taking into account the theoretical premise that the actual driving forces of growth of a company may not be relative levels of performance in a certain period of time, but their dynamics and variation over time. The dynamic component $\left(S_{\Delta \pi_{i: t}}^{2}\right)$

is the average value of the logarithm of the difference in productivity over two consecutive years, and the static component is calculated as the average intra-company level of performance for periods $\mathrm{t}$ and $\mathrm{t}-1$.

A detailed description of the applied methodology is presented in Dosi et al., 2015 and Savin et al., 2019.

\section{$4 \quad$ Results and Discussion}

We present the results for each of the three mentioned indicators in Table 1. First, we observe that explanatory ability of the dynamic component of all indicators, evaluating the impact of changes in each on the growth of companies, significantly exceeds the value of the static component. For labor productivity and total factor productivity the dynamic component explains on average up to $10 \%$ of total firm growth. The explanatory ability of dynamic component of profit is stronger (up to $16 \%$ ).

Comparing three performance indicators, we see that the median values of total explanatory ability are close for the labor productivity and total factor productivity. This holds true also on the level of individual industries. The results for profit per employee provide slightly higher median estimate. While it is likely true that firms in real world are most interested in maximizing their profits, and not just revenues or productivity, our results here do not provide a strong evidence supporting the claim that competition is better observed if we look on profits and not on productivity or revenue.

Thus, we find that the influence of market selection on the growth of firms is significant and in total explains the median of about $10 \%$ of the variation in the dynamics of growth of firms when we use labor productivity and TFP as predictors, and about $16 \%$ if we choose such factor as profit per employee defined as a difference between company's total revenue and total costs, divided by the number of employees. The estimates obtained (with TFP and labor productivity) are lower than the estimates of the role of market forces for revenue growth presented in Dosi et al. (2015) ranging from $13-14 \%$ for the UK and US and 16-18\% for Germany and France. 
Tab. 1: Econometric assessment of impact of different factors on aggregate performance growth by NACE 2 industries

\begin{tabular}{|c|c|c|c|c|c|c|c|c|c|c|c|c|}
\hline & \multicolumn{4}{|c|}{ Labor productivity } & \multicolumn{4}{|l|}{ TFP } & \multicolumn{4}{|c|}{ Profit } \\
\hline & $s_{\overline{\pi_{L f f}}}^{2}$ & $S_{\mathbb{U}_{\mathrm{iff}}^{2}}^{2}$ & $s_{\text {total }}^{2}$ & $R_{\text {total }}^{2}$ & $S_{\frac{2}{\bar{u}_{\mathrm{Lif}}}}^{2}$ & $S_{\mathbb{U}_{\mathrm{iff}}}^{2}$ & $s_{\text {total }}^{2}$ & $R_{\text {total }}^{2}$ & $S_{\overline{u_{u f f}}}^{2}$ & $S_{\mathrm{Uin}_{\mathrm{iff}}}^{2}$ & $s_{\text {total }}^{2}$ & $R_{\text {total }}^{2}$ \\
\hline Food products & 0,002 & 0,07 & 0,07 & 0,32 & 0,004 & 0,06 & 0,06 & 0,30 & 0,005 & 0,11 & 0,11 & 0,39 \\
\hline Beverages & 0,006 & 0,11 & 0,12 & 0,29 & 0,006 & 0,11 & 0,11 & 0,28 & 0,009 & 0,17 & 0,18 & 0,39 \\
\hline Tobacco & 0,020 & 0,28 & 0,30 & 0,61 & 0,016 & 0,25 & 0,27 & 0,58 & 0,014 & 0,30 & 0,32 & 0,61 \\
\hline Textile & 0,004 & 0,07 & 0,07 & 0,28 & 0,008 & 0,07 & 0,07 & 0,27 & 0,004 & 0,13 & 0,13 & 0,37 \\
\hline Wearing apparel & 0,000 & 0,08 & 0,08 & 0,27 & 0,001 & 0,07 & 0,07 & 0,25 & 0,001 & 0,14 & 0,14 & 0,34 \\
\hline Leather & 0,002 & 0,05 & 0,05 & 0,22 & 0,004 & 0,05 & 0,05 & 0,22 & 0,004 & 0,09 & 0,10 & 0,28 \\
\hline Wooden products & 0,004 & 0,07 & 0,07 & 0,26 & 0,005 & 0,07 & 0,07 & 0,25 & 0,005 & 0,12 & 0,13 & 0,34 \\
\hline Paper & 0,001 & 0,05 & 0,05 & 0,34 & 0,002 & 0,04 & 0,04 & 0,33 & 0,003 & 0,11 & 0,11 & 0,42 \\
\hline Recorded media & 0,000 & 0,03 & 0,03 & 0,39 & 0,001 & 0,03 & 0,03 & 0,38 & 0,000 & 0,06 & 0,07 & 0,46 \\
\hline Coke and refined petroleum & 0,001 & 0,13 & 0,13 & 0,44 & 0,002 & 0,10 & 0,11 & 0,42 & 0,002 & 0,14 & 0,14 & 0,55 \\
\hline Chemical products & 0,000 & 0,10 & 0,10 & 0,26 & 0,001 & 0,09 & 0,09 & 0,25 & 0,004 & 0,16 & 0,16 & 0,35 \\
\hline Pharmaceuticals & 0,005 & 0,14 & 0,14 & 0,38 & 0,007 & 0,13 & 0,14 & 0,37 & 0,005 & 0,18 & 0,19 & 0,43 \\
\hline Rubber and plastic products & 0,002 & 0,06 & 0,07 & 0,30 & 0,004 & 0,06 & 0,06 & 0,29 & 0,003 & 0,13 & 0,13 & 0,39 \\
\hline Non-metallic products & 0,001 & 0,09 & 0,09 & 0,36 & 0,002 & 0,08 & 0,09 & 0,36 & 0,001 & 0,14 & 0,14 & 0,45 \\
\hline Basic metal & 0,000 & 0,12 & 0,12 & 0,35 & 0,001 & 0,10 & 0,10 & 0,33 & 0,001 & 0,15 & 0,15 & 0,41 \\
\hline Fabricated metal & 0,001 & 0,09 & 0,09 & 0,22 & 0,002 & 0,09 & 0,09 & 0,21 & 0,003 & 0,16 & 0,16 & 0,31 \\
\hline Computers and electronics & 0,001 & 0,16 & 0,16 & 0,35 & 0,002 & 0,16 & 0,17 & 0,35 & 0,001 & 0,21 & 0,21 & 0,42 \\
\hline Electrical equipment & 0,002 & 0,10 & 0,10 & 0,30 & 0,005 & 0,10 & 0,10 & 0,29 & 0,001 & 0,17 & 0,17 & 0,38 \\
\hline Machinery & 0,000 & 0,10 & 0,10 & 0,22 & 0,001 & 0,11 & 0,11 & 0,22 & 0,002 & 0,18 & 0,18 & 0,32 \\
\hline Motor vehicles & 0,000 & 0,12 & 0,13 & 0,35 & 0,002 & 0,12 & 0,12 & 0,34 & 0,002 & 0,15 & 0,16 & 0,39 \\
\hline Transport equipment & 0,001 & 0,15 & 0,15 & 0,28 & 0,000 & 0,15 & 0,15 & 0,28 & 0,001 & 0,23 & 0,23 & 0,37 \\
\hline Furniture & 0,000 & 0,09 & 0,09 & 0,35 & 0,000 & 0,08 & 0,08 & 0,34 & 0,000 & 0,17 & 0,17 & 0,46 \\
\hline Other manufacturing & 0,005 & 0,09 & 0,10 & 0,31 & 0,011 & 0,10 & 0,11 & 0,30 & 0,006 & 0,17 & 0,18 & 0,40 \\
\hline Mean & 0,003 & 0,10 & 0,10 & 0,32 & 0,004 & 0,10 & 0,10 & 0,31 & 0,003 & 0,16 & 0,16 & 0,40 \\
\hline Median & 0,001 & 0,09 & 0,10 & 0,31 & 0,002 & 0,09 & 0,09 & 0,30 & 0,003 & 0,15 & 0,16 & 0,39 \\
\hline
\end{tabular}

Source: own estimations based on Ruslana data 


\section{Conclusion}

This paper contributes to the analysis of several firm performance indicators for estimating market selection forces on the industrial level by using econometric estimation method. Namely, we consider labor productivity, total factor productivity and profit per employee. We have used the data of 79 thousand Russian manufacturing firms for the period from 2006 to 2017.

The main result implies that the bulk of the impact of productivity variables relates to efficiency changes more than to absolute differences of productivity levels across firms. This result is similar for all the factors we analyzed. Comparing three performance indicators, we see that the median values of total explanatory ability are close for the labor productivity and total factor productivity. This holds true also on the level of individual industries. The results for profit per employee provide slightly higher median estimate. While it is likely true that firms in real world are most interested in maximizing their profits, and not just revenues or productivity, our results here do not provide a strong evidence supporting the claim that competition is better observed if we look on profits and not on productivity or revenue.

As a prospect for further research, we would like to consider other indicators such as return on assets/equity/investment. We could not do this now because they are not available in the Ruslana database. It is also possible to conduct an analysis to determine the strength of market selection for private and public enterprises.

\section{$6 \quad$ Acknowledgement}

This research was supported by the grant of the President of Russian Federation for the support of young Russian scientists number МД-3196.2019.6.

\section{References}

Al-Matari, E., Al-Swidi, A., Fadzil, F. (2014). The Measurements of Firm Performance's Dimensions. Asian Journal of Finance \& Accounting, 6(1), 24-49.

Bottazzi G., Secchi A. (2012). Productivity, profitability and growth: the empirics of firm dynamics. Structural Change and Economic Dynamics, 23(4), 325-328.

Brown J. D., Crespi G.A., lacovone L., Marcolin L. (2018). Decomposing firm-level productivity growth and assessing its determinants: evidence from the Americas. The Journal of Technology Transfer, 43(6), 1571-1606.

Coad A. (2007). Testing the principle of 'growth of the fitter': the relationship between profits and firm growth, Structural Change and Economic Dynamics, 18(3), 370-386.

Delmar F., McKelvie A., Wennberg K. (2013). Untangling the relationships among growth, profitability and survival in new firms. Technovation, 33, 276-291.

Dosi, G., \& Grazzi, M. (2006). Technologies as problem-solving procedures and technologies as inputoutput relations: Some perspectives on the theory of production. Industrial and Corporate Change, 15, 173-202.

Dosi, G., Pugliese, E., Santoleri, P. (2017). Growth and survival of the "fitter"? Evidence from US new-born firms, LEM Working Paper Series, No. 2017/06, Scuola Superiore Sant'Anna, Laboratory of Economics and Management (LEM), Pisa. 
Dosi, G., D. Moschella, E. Pugliese \& Tamagni, F. (2015). Productivity, market selection, and corporate growth: comparative evidence across US and Europe. Small Business Economics, 45, 643-672.

Dvouletý, O., Srhoj, S., \& Pantea, S. (2020). Public SME grants and firm performance in European Union: A systematic review of empirical evidence. Small Business Economics.

Foster, L., Haltiwagner, J., Syverson, C. (2008) Reallocation, Firm Turnover, and Efficiency: Selection on Productivity or Profitability? American Economic Review, 98, 394-425.

Griliches, Z., \& Regev, H. (1995). Firm productivity in Israeli industry 1979-1988. Journal of Econometrics, 65, 175-203.

Savin I., Mariev O., Pushkarev A. (2019). Survival of the fittest? Measuring the Strength of Market Selection on the Example of the Urals Federal District. HSE Economic Journal, 23(1), 90-117. (In Russian).

Savin, I., Mariev, O., Pushkarev A. (2020). Measuring the strength of market selection in Russia: When the (firm) size matters. Voprosy Ekonomiki,2, 101-124. (in Russian).

Van Beveren, I. (2012). Total factor productivity estimation: A practical review. Journal of Economic Surveys, 26(1), 98-128. 